FRANCES (SANDY) DUNCAN is a Vancouver writer. Some of her books include The Toothpaste Genie, Kap-sung Ferris, Dragonhunt. Recently she has been applying ferninist criticism to children's literature. In 1987 she will be writer-in-residence at the I'niversity of Winnipeg.

\title{
Whither Story Wither Story With Her Story
}

\author{
FRANCES DUNCAN
}

When I think of patriarchal aspects of language - its words, meanings, structure - the phallic logos, I see Dragnet's Joe Friday saying to a woman who has opened the door to his knock: "Just the facts, ma'm, just the facts." He elicits his facts from her by masterful use of silencing techniques: the bored "uh huh", the pained glance at his partner, the shift of his body, the disinterested expression when she is 'disgressing'. I am given my last view of her dithering blackly and whitely on her doorstep while I with the camera, with Sergeant Friday climb into his car feeling both perfidious and superior, for I know that had he asked me for just the facts, I could have given him them, because in the collusion of language, of story I have learned what his facts are.

If one of the facts Joe Friday wanted was my age, I would know to say: "I am forty-three." I know to say that because I know how his facts are organized - linearly, logically, and numerically - into his story line. I know how he has decreed years be counted, the system he counts by, the period of time he counts, and that he has judged at which moment (when I first cried in air) I became a(c)countable.

I am forty-three is a story. (from Gk. historia: inquiry, information, narrative; histor - judge, ì Gk. see. Story: a connected narrative of important events, a sequential accounting of facts, a narrative of incidents arranged according to their time relationship.) I am forty-three has a beginning, $I$, a middle, am and an end, forty-three. all arranged sequentially. It has a point of view - his (by decreeing the system of counting which sets up the plot line he has author-ity). It has action, am, which is being frozen for a moment of examination by the point of view, a character, $I$, which Joe Friday as author has created and is describing through his system of counting, and the story has a fact which contains a sense of time - forty-three.

A story must be more than a recitation of facts; it must have a shape and 
a sense of vision. This story has a linear shape and an arithmetic vision. As such it is not going to get very far -I am forty-three can continue to progress only until $I$ am sixty-two or seventy-nine - if I have not expired in a sigh of boredom at forty-five. This is not a story of significance to me; I would put it down. Yet that is odd: I should be the most interested in my own age; it's not just a fact, it's a personal fact. Exactly. A fact about one person - but who? Not me. Sergeant Friday perhaps.

He would be satisfied with my/his storyline. He would give it/me?/ him? his tight-lipped smile, and climb into his black and white car, leaving me dithering on the doorstep as I try to move back into the I of I am fortythree. Am I not my own subject? Of course I am. Then why are bits of me littering my doorstep on either side of 'my' story?

The fragmentation of $I$ occurs because of the confusion of the $I$ that is his character (creation, object), with the taste and shape of the $I$ in my mouth (my sense of being my own subject), just as the fragmentation of the doorstep woman occured when Joe was not interested in her story, but only in his 'facts'. I can only write Joe's story (at his request) I am forty-three by assuming a phallo-logos colluding persona for authority, by dissociating from my $I$ as subject so I can become my own object.

When I pull the $I$ of the story back into myself, I roll that $I$ on my tongue, part of my lips around it and breathe it onto the paper and so fuse the written $I$ with the writing $I$ and become my own, no longer fragmented subject, when I do that I cannot write that story. It is not my story. I want Sergeant Friday out of my author-ity. At the most, if he is willing, he may sit in a comfortable chair and actively listen to -..-

My story on the theme of my age encompasses all ages I have been and will be, memories - recalled, recreated, reexperienced, projections, images of older ages I will be, and a flowing between them all. My story of my age is now; it holds my awareness of all ages. My story of the ages that I am changes and shifts as I write it. A woman writing herself is a shape-shifter. My story is my life and my life is my story. I shape it, I en-re-vision it. I tell it, I live it, it changes and I change, and as I tell my story it changes me and so I tell it changed.

I want to tell my story because I want to claim my life. I want to make sense (shape, vision) of the (apparently) senseless, to comprehend (take hold of, touch) those parts of my life that were-have been-are incomprehensible. I want to know what has-is-will be happening as I could not when I was a child, when I did not have the skills to understand (I stood under not beside) and was told: "Don't bother me", "Don't interrupt", "Speak when you are spoken to", "You'll understand when you're older", "What a funny thing to say", "Don't use that word", and of course "Just the facts, ma'm". And so often the silence of grown-ups, my first (was it?) experience of white space. In this I learned to write: file instead of life, left instead of felt, evil instead of live; was told I was reversing. Was I?

With Yvonne in PATTERN MAKERS I take a step in writing my story 
by claiming my words, my facts, by distinguishing the frozen appliance words from the breathing words of my birth. Yet stories are not told in isolation, stories of more than one person are told at intersections, words live only through sharing, and the vision to shape the story-life comes only, as Yvonne-I found out, through a visit to the Persephone depths, a washing in the ocean, a glimpse of another world. Only then do I have strength to shut the door on Sergeant Friday's, "just the facts, ma'm" and keep my I's for my visions.

In this texture (not a subtext, implying hierarchies of importance, but interwoven and feelable) from PATTERN MAKERS Yvonne tells of the search for her own words so she can tell her own story which of course is part of the story she is telling----

Yvonne said, "I was living in my fridge and then I got out and it disappeared. Everything disappeared. Then I met the spider by a rose bush. It started following me, then the mirror made an abyss--.." She frowned at her sentence hissing like a disconnected hose. The words were weak, incomplete, did not truly describe---.

Yvonne was now lying curled on her side, moaning, panting. "If I didn't know better," she said between spasms, "I'd think I was in labour."

"You don't look pregnant," Jane said.

"I'm not." pant "There's no" pant "way I can be."

"A miscarriage?" Mirabelle stroked the hair off her forehead.

Pant "can't" pant "be----oh!"

"Guess you are," Jane observed. "Your water's have just broken. Oh it's not water, how odd."

Mirabelle's face was as white as Yvonne's. "What are we going to do? We don't have any hot water, any cloths-.-."

Jane waddled closer. "We'll manage. You've had babies and I used to be a midwife. Remember Yvonne's teeth, one thing she has is lots of water."

"Yvonne had undone her jeans; now Mirabelle helped her take them off. Jane crouched down so Yvonne had her shell for support. "Keep panting," Jane said, "until you feel like pushing."

"Different - from my - other - births - sharp, something's too sharp Ow." Mirabelle held out her hands and Yvonne grasped them, squeezed. Blood, not amniotic fluid on her thighs.

"Oh dear." Jane tried to not feel scared, tried to remember about hemmorhages. 
Yvonne made her teeth gush water to wash the blood away, shivered with fear. The spider inched closer, only a foot away now, continued to watch. Yvonne closed her eyes, and tears squeezed out. They mingled with the sweat on her cheeks, neck, fell onto her shirt. When she looked again, everything was filmed - an unfocussed lens - except for the spider. Something - an expression - on its face reassured her.

Then she was drawn inside, could feel from inside her outside hands rubbing the skin on her abdomen, could feel her uterus bloated, swollen, so sensitive to pressure - felt the stretching, pulling, opening of her cervix, her vagina felt sharpness against her cervix, scraping down her vagina too dark inside to see, could only feel inside, from inside she tried to smooth the way with her hands, pushed the walls of her vagina apart to make room, protected its surface with her hands, with her arms, from the scraping of the sharp birth object, aware of rustlings, stirrings still in her uterus, used her outside hands to pluck whatever baby from her vulva.

Trembling, all of her, Mirabelle rubbing her lower back with one hand, supporting her shoulders with her other arm. The solid warmth of Jane to lean on, her head turned around, her eyes soft and worried.

Mirabelle looked up, saw the softness in Jane's eyes, smile. She'd always known it was there. Somewhere.

An uncontrolled fountain of water gushed from Yvonne's teeth, and she rinsed what she had born in its spray-..-

Paper. A ream of paper. Blank. White. Manuscript size. Her terror grew, and the shivers became shakes, she was still gushing water, and now inside her uterus the flutterings, the ticklings increased, and she was shaken from inside as well, the flutterings vibrated down her vagina like little burps of air, poof poof poof and exploded into tickles at the exit----

Words. All sort of words, some large, some small, some snake-like ones that wiggled off into the grass, some fat and pink like baby angels or exotic birds. These ones flew away. Others dissolved in the fountain spray from her teeth. The air was full of words like soap bubbles or like moths, the ground was covered in wiggling, writhing words like snakes or worms, words hung from the branches overhead, nesting birds and sleeping bats. Yvonne closed her mouth, stopped the gushing of her teeth, put out a hand to catch some words, but they eluded her fingers. Jane snapped at words as they passed her beak and tried to put her flipper over those wiggling on the ground. Mirabelle chased back and forth like a butterfly catcher - unsuccessfully. Yvonne held out the paper but none would land, and soon all the words had flown or crawled away.

Yvonne cradled the paper to her breast, sobbed, rocked back and forth, rocking the paper, rocking herself, sobbed. She felt sore, battered inside, she'd used too much water, felt dry, hardly enough for tears - and now, sobbing wordlessly, the bereavement of a stillbirth - still, a birth. Rocked the paper against her breast, as blank as she was empty inside, still---- 
Mirabelle had her arms around her, Jane was rubbing her back, both of them crying too. Yvonne opened her eyes, blinked the tears off her lashes, saw her blood-streaked thighs, looked up.

The spider crouched in front of her, holding something in its two front legs - a word. A very little word. Yvonne held out the paper and the spider placed the word upon it. ME. She stared at the word on the paper, felt herself smiling at it, smiled at the spider - then realized her left hand was clutched around something - she opened it. I lay there, straight and sharp. She put it on the paper too, held it out for the others to see. 1 and $M E$. Below them, curled like a question mark, rested a wiry, dark blonde pubic hair.

She didn't want to think about how the dancing had made her feel: old feelings of dancing free as a child, newer feelings of self-consciousness, inadequacy, not knowing the steps. She didn't want to think about whether she'd created the party, or what it meant that things happened if she just thought about them - and sometimes when she wasn't thinking----She didn't want to think if she was angry the men had stolen the computer, or how she felt about the spider or about giving birth to paper and disappearing words. No, it wasn't that she didn't want to think, it was that she couldn't think. She didn't have words.

They'd all flown away - why? Her unplanned statement about sucker and fucker made her look at those words as words, realize how many there were she had not looked at, did not know, could not use. A burbling, turgid swamp inside her she could not describe, define, separate, known or own because she did not have the words-.--

She saw a fridge door closing, looked to the side, her vision pulled by tendrils of wanting one seconds ago, looked back to her paper. She thought: words like fridge doors, frozen words, words she'd learned to use like machinery or appliances, where were her words that lived, were warm, pulsated with her blood?

She could see pictures - not as well as she wanted to, but - could move into them, could let others see, but she could not paint her pictures with words so they would last. And Jane's charge that she was creating all this that they moved through, all the things that had happened confused her. It felt more that what they were moving through, all the things that had happened were creating her. Thinking about that made her feel -a burbling, turbid swamp -..-

In the swamp grew a cottonwood with spreading tangled roots. Its branches were full of birds, singing, chattering, calling. She could hear them, could see birds perched on branches, could see the word bird perched on branches, crow, robin, starling, finch, could see the words spread wings 
and flap them, fly away, still chattering, word, word, word. The leaves of the tree were words too, fluttering in the breeze, and the trunk was made of words, vertical, striated, tightly overlapping.

Yvonne ran to the tree, laid the paper at its base, shinnied up the trunk, scratching herself on the bark-words. But as she got closer to the branches the word-leaves curled off their stems like autumn was happening or a disease and slowly fell to the ground. She climbed down and ran to the fallen leaves, bent to scoop up handfuls, but now a ground breeze lifted them and swirled them and the air was full of words. She tried to grab them as they floated past but the wind increased and the words were all blown back to the branches, hung again from their stems. With a great calling and flapping and rustling the birds flew back into the tree where they perched and chattered as if mocking her attempts. Sobbing, screaming with frustration, Yvonne tore at the bark of the trunk, scraping her fingers, breaking a nail, determined to have at least one word. She broke off a small bit, tried again, both hands around a chunk, but it would not yield. The birds chattered more loudly and the leaves rustled and the branches rubbed together and she felt all the words in the world were laughing at her.

She looked at the piece she'd broken off, placed it on the paper, centered it, moved it around, tried it in the corners, by itself, in front of $I$, in front of $M E$, above them and below. Finally she stuck the word in the middle, pressed it firmly with her palm, studied it.

I AM ME

Satisfied with that arrangement, she blew on it -to dry it, or remove grit. The hair, curled like a question mark, floated off the paper, was lost in the grass. She'd thought it firmly stuck.

$\&$

She was left in the dusk at the bottom of the ocean. She screamed her horror, frustration, disappointment and the scream left her mouth in rising bubbles of air that mixed with air escaped from the other world.

And now the one shift necessary to close up the crack set others in motion. The floor trembled and rumbled, rocks fell down, ledges grew up, the 
increasing turbulence jarred her, terrified her, she was holding her breath under water, catapulted her halfway to the surface.

She pushed upward, following the stream of bubbles from her scream, from the other world, responding to the pain in her lungs, her ears, her throat, kicked hard and hard, upward to the air so far above, its imperative through all of her, she had burned away her body fluids and the water on her skin was first an irritation, then an agony, her mouth about to open to be filled with water.

She broke the surface, gulped great mouthfuls of air, she could not breathe in water, and all around her the bubbles of her scream broke the surface with little popping sounds, and as they did they turned into words that floated on the surface of the water, floated closer and closer as if drawn to her and when they touched her skin they clung to it all over like oil in water or moisturizing cream, and she felt she'd grown a new layer of skin and that layer was her words.

$\&$

Jane said, "I don't really know what I'm going to do while Mirabelle's growing tulips and you're writing, but I guess sumthing will turn up---.." She looked sharply at Yvonne. "I said something. When you say something, you can write sumthing. Transcribe yourself, not me."

"I didn't want it confused with samething, $a$ 's and $o$ 's, you know - but that's what I've been doing," she held up her paper, "transcribing myself, want to hear?"

"I thought we had been," Mirabelle said.

"It's different now I've got my own words. It starts, 'Dark in the fridge and stiff, cramped, I open the door...." 